\title{
A TESTKÉP KOMPLEXITÁSA ÉS A SZERV- ÁTÜLTETÉS SIKERESSÉGE. VESETRANSZPLANTÁLT PÁCIENSEK LONGITUDINÁLIS VIZSGÁLATA*
}

\author{
LÁTOS MELINDA ${ }^{1}$ - DEVECSERY ÁGNES ${ }^{2}$ - LÁZÁR GYÖRGY ${ }^{1}$ - \\ HORVÁTH ZOLTÁN ${ }^{1}$ - SZENOHRADSZKY PÁL ${ }^{1}$ - SZEDERKÉNYI \\ EDIT $^{1}$ - CSABAI MÁRTA ${ }^{2}$ \\ ${ }^{1}$ Szegedi Tudományegyetem Sebészeti Klinika; \\ ${ }^{2}$ Szegedi Tudományegyetem Pszichológiai Intézet \\ E-mail: latosmeli@gmail.com
}

Beérkezett: 2013. március 17. - Elfogadva: 2014. július 6.

Háttér és célok: Az utóbbi évek interdiszciplináris kutatásai felhívják a figyelmet, hogy a szervátültetés következtében meguáltozhat a test szubjektíven észlelt egysége, sérülhet a testkép integritása, komplexitása (CALIA és mtsai, 2011; PASQUALE és mtsai, 2010). Kutatásunkban elsödleges célként tüztük ki a transzplantáció utáni testkép-jellegzetességek feltérképezését és azok hatását az új szerv optimális, hosszú távú müködésére.

Módszer: 50, vese-transzplantáción átesett személlyel a Spielberger-féle Állapot-és Vonásszorongás Kérdöívet, a Beck Depresszió Skálát és egy saját tervezésü projektív rajztesztet (sajátalak- és veserajz) vettünk fel. A páciensek felépülését három évig követtük nyomon, negyedévente rögzítve a vesefunkciós értékeket és a kilökődési epizódokat.

Eredmények és következtetések: A szorongóbb és depresszívebb pácienseknél a projektív rajztesztben a transzplantált szerv nagyobb méretben jelent meg, ami az átültetett vese intrapszichés integrációjának a zavarára utalhat. Logisztikus regressziós modellben a hazabocsátáskor mért szérum kreatinin érték és a testkép komplexitása prediktív a beültetett vese hosszú távú müködésében. Kutatási

\footnotetext{
* A kutatás a TÁMOP-4.2.4.A/2-11/1-2012-0001 azonosítószámú Nemzeti Kiválóság Program - Hazai hallgatói, illetve kutatói személyi támogatást biztosító rendszer kidolgozása és működtetése konvergencia program címủ kiemelt projekt keretében zajlott. A projekt az Európai Unió támogatásával, az Európai Szociális Alap társfinanszírozásával valósul meg.
} 
eredményeink szerint a transzplantációt követö testképváltozások negatív hatással lehetnek a páciens egészségi állapotára és hosszú távon hozzájárulhatnak a beültetett szerv kilöködéséhez.

Kulcsszavak: testkép, vese-transzplantáció, rajzteszt, szorongás

Az utóbbi évek kutatásai egyre nagyobb figyelmet fordítanak a transzplantált páciensek pszichés állapota és a szervátültetés következtében létrejövő testképzavarok feltérképezésére (CALIA és mtsai, 2011; Ilić és Avramović, 2002; PASQUale és mtsai, 2010; PÉrez-SAN-Gregorio, Martín-Rodríguez, Galán-Rodríguez és BORDA-MÁs, 2009). Az idegen szerv pszichés integrációjának jelentőségét - amely az érzelmi és pszichológiai jóllét feltétele - több szerző is hangsúlyozza (BASCH, 1973; Castelnuovo-Tedesco, 1983; Látos és mtsai, 2012; Shimazono, 2013).

A transzplantáció nem csupán fizikailag jelent nagyfokú megterhelést a páciens számára, hanem pszichésen is: az életet fenyegető betegség jelenléte, az átélt fájdalmak, a szervvel kapcsolatos fantáziák és tudattalan érzelmek, a hosszan tartó szorongásos állapot kimeríthetik az egyén tartalékait. Ambivalens érzések törnek a felszínre: egyrészt feléled a remény a teljes, egészséges élet iránt, másrészt megjelenik a bizonytalanság, a tehetetlenség, a kiszolgáltatottság érzése, a haláltól és a kórházi kezelésektől való félelem, csökken az autonómia és az önbecsülés érzése (CONSOLI, 2012). Megbomlik a szelf integritása és megjelenhet a donor felé érzett bűntudat is. A testi élmények dezintegrált módon jelennek meg a fantáziában: az énhatárok fellazulhatnak, a testrészek fragmentálódhatnak (CONSOLI, 2012; CSABAI és ERŐs, 2000). A páciens igyekszik helyreállítani saját testképének egységét, ami a transzplantált szerv mentális és szomatikus szinten történő befogadását jelenti. Azonban a szerv mentális integrációja, harmonikus beépülése a testképbe komplex feladat, az ide vezető út pedig hosszú és megkerülhetetlen.

Több kutatásban próbálták igazolni a transzplantációs mủtét utáni testképtorzulásokat és pszichés ártalmakat, azonban a választott módszer nem mindig volt alkalmas e komplex jelenségnek a megfogására. A testkép igen képlékeny, dinamikus koncepció, mely betegség idején negatív irányba változhat, amely nem csupán az adott beteg szervre vagy testrészre vonatkozik, hanem rávetülhet az egész testtel kapcsolatos érzékelésre is (CSABAI és ERŐs, 2000). A megváltozott testképhez való alkalmazkodás pedig akár egy évig is eltarthat (TAYLOR, 1986). Kizárólag kérdőíves technika alkalmazásával nem találtak szignifikáns különbségeket a testkép és az önértékelés mentén, vesetranszplantált, illetve egészséges fiatalokat vizsgálva (MELZER, LEADBEATER, REISMAN, JAFFE és LIEBERMAN, 1989). Veseátültetésen átesett személyek pszichopatológiai jellegzetességeit kutatva emberrajz teszt segítségével azonban kimutatták, hogy a szervátültetés potenciális kockázatot jelent a páciens számára, amelynek során elvész a test szubjektíven észlelt egysége (DE PASQUALE et al., 2010). Bár a mütét gyorsan visszaállítja az anatómiai és a fiziológiai funkciókat, ezzel párhuzamosan az emocionális és a kognitív szinten történő integráció (pszichés transzplantáció) is szükséges. A páciensnek el kell gyászolnia az elveszített szervét, amely tovább már nem látja el funkció- 
ját, fel kell dolgoznia a donor felé érzett bűntudatát. A szerzők kiemelik, hogy a szervátültetés után a beteg testében és testképében azonnali változás megy végbe, amely pszichoszomatikus válságot provokálhat. E krízisnek a megoldása a testkép és az elsődleges Én újjáépítése a szerv mentális integrációja által. Az elsődleges én a csecsemő alapvető egységére utal, ahogyan egyfajta pszichoszomatikus egészként működik (FORDHAM, 1971; URBAN, é.n.). A fogalom a kezdeti állapotot jelöli, amelyből a fejlődés elindulhat, mivel minden potenciál benne rejlik.

CHATURVEDi és PANT (1984) tanulmányukban Draw-A-Person rajztesztet alkalmaztak, amely segítségével közelebb kerülhetünk a transzplantált személyek testképében bekövetkezett változásokhoz. Eredményeik szerint a kontrollcsoporttal összehasonlítva a vesetranszplantált férfiak rajzai kisebb méretűek és számos részlet (ujj, ruházat) hiányzott az alakról, gyakran radírozgattak és aszimmetrikusabb képet készítettek, amely bizonytalanságot, szorongást, kiegyensúlyozatlan énképet és alacsony önértékelést jelez. Nesci, Favale, Foco, CASTAGNeto és NANNI (2001) szintén projektív tesztekkel vizsgáltak 16 vese-transzplantáción átesett pácienst. Az emberrajzokat elemezve a szerzők szintén megfigyelték az egyes testrészek (láb, kar) hiányát és a kontúrok gyengeségét, szakadozottságát. A fizikai határok ugyan jelen voltak, de rosszul definiáltak. Értelmezésükben a test konténerfunkciót tölt be, amely elősegíti az idegen szerv asszimilálódását, azáltal pedig csökkenti a rejekciótól való félelmet. A páciens egyfelől arra kényszerül, hogy újradefiniálja saját testképét, másfelől a donor felé megjelenő gyász érzésével is meg kell küzdenie. A rajzok elemzése során a színek használatának is fontos szerepe van. A sötét színek (fekete, barna) használata a bizonytalanság, a szorongás, a harag, a fájdalom és a félelem érzéséhez kapcsolódnak (VASS, 2006, 2011). Az emberrajztesztnél a felhasznált színek normatív száma 3-5 szín. Beszűkült színhasználatról beszélünk, ha a személy csupán egy színt alkalmaz.

Egy longitudinális ausztrál tanulmányban 32 szívbetegségben szenvedő, 49-54 éves hölgyet arra kértek, hogy rajzolják le szívbetegségüket (GuILlEmin, 2004). A szerző szerint a rajzok elemzése nagyon izgalmas feladat, egy olyan újszerű kutatási módszer, mely segítségével megvizsgálhatjuk és elemezhetjük az egyén betegségről alkotott képét. A rajz a testet öltött betegség, mely arról árulkodik számunkra, hogy hogyan éli meg, hogyan fogja fel a páciens betegségét. Új-Zélandon a kardiológiai központ szívelégtelenségben szenvedő pácienseinél szintén rajztesztet alkalmaztak a pszichés és a klinikai állapot összefüggéseinek a megállapítására (Broadbent, Petrie, Ellis, Yinga és Gambl, 2004; Petrie és Weinman, 2012; Reynolds, Broadbent, Ellis, Gamble és Petrie, 2007). A pácienseket megkérték, hogy rajzolják le a szívüket, ahogyan azt elképzelték a betegség előtt, illetve utána. Eredményeik alapján azok a páciensek, akik nagyobb rajzot készítettek, a szívükkel kapcsolatban szignifikánsan kifejezettebb szorongásról számoltak be. Azok a páciensek, akik valamilyen sérülést is megjelenítettek a lerajzolt szívükön, sokkal nagyobb depressziót éltek át, a betegségükkel kapcsolatban negatívabb attitűdökkel rendelkeztek, és több idő eltelte után tértek csak vissza a munkájukhoz, mint azok, akik károsodás nélkül jelenítették meg a szervet. A klinikai adatok és a rajzteszt sajátosságai között is összefüggések mutatkoztak. A szívre rajzolt károsodás jobban előrejelezte a páciens felépülését, mint bármely más orvosi mutató. 
Vizsgálatukkal igazolták, hogy a rajztesztek alkalmazásával egy olyan innovatív technikát lehet kidolgozni, amelynek segítségével pontosabb képet kaphatunk a páciensek betegséggel kapcsolatos hiedelmeiről és attitűdjeiről, amelyek prediktívek a felépülés és a túlélés tekintetében. Eredményeik felhívják a figyelmet a pszichoedukatív technikák alkalmazására, amelyek segítségével csökkenthetjük a páciens negatív attitűdjeit betegségével kapcsolatban, ezáltal elősegítve a gyógyulási folyamatot.

A rajztesztek hagyományos alkalmazási területei közé tartozik az énkép és a testséma vizsgálata, az énerő, a regresszió és a traumák vizsgálata (BAGDY, 1998; MACHOVER, 1949, 1951; VASS, 2006, 2011). Hárdi István több évtizedes klinikai tapasztalatból és több tízezer rajz elemzéséből arra a következtetésre jutott, hogy az emberrajzok olyan objektív mérőeszközök, amelyek a személyiség integrációjáról és az esetleges regresszív folyamatokról árulkodnak (HÁRDI, 2002; VASS, 2011). Hárdi elméletében a rajz személyiségszintje, stílusa egészséges emberben állandó, azonban az ember testi-lelki állapota rávetül az alkotásra, így bármiféle állapotrosszabbodással és gyógyulással együtt változik. Természetesen a gyakorlásnak és a foglalkozásnak hatása lehet a rajzra, időseknél pedig a megváltozott pszichomotorium hagyhat nyomot a vonalvezetésben. Azonban a legfontosabb szerep mégis a személyiségnek jut, mivel a fent említett tényezők csak az ember személyiségén átszűrve valósulhatnak meg. Ezáltal a megalkotott kép a tudattalan megismerésére is lehetőséget nyújthat, a személyiség mélyebb rétegeiről is számot ad.

Feltételezésünk szerint a transzplantáció által indukált intrapszichés konfliktusok feltérképezése és megértése előrejelezheti a gyógyulási folyamatot, a szervátültetés hosszú távú eredményét. A transzplantáció megbonthatja a testkép integritását, ezért elsődleges célunk volt, hogy feltérképezzük a transzplantáció utáni testkép-jellegzetességeket és azok hatását az új szerv működésére. Továbbá a páciensek érzelmi és hangulati állapotát is felmértük, majd összevetettük a vese allograft hosszú távú működésével. Feltételeztük, hogy a testkép komplexitása és az új szerv mentális reprezentációinak sajátosságai összefüggésbe hozhatók a gyógyulási folyamat minőségét tükröző élettani mutatókkal és az affektív jellemzőkkel. A vizsgált változók között cirkuláris kapcsolatok meglétét tételezzük fel. Kutatásunkban három évig követtük nyomon a transzplantált pácienseink gyógyulását.

\section{MÓDSZER}

\section{Résztvevők és a vizsgálat körülményei}

2009 decemberében kezdtük el 3 éves longitudinális kutatásunkat a Szegedi Tudományegyetem Sebészeti Klinikájának Transzplantációs Osztályán. Minden pácienssel egy komplex pszichológiai tesztbattériát vettünk fel a transzplantációs műtétet követően, majd három évig nyomon követtük gyógyulásuk alakulását, negyedévente rögzítettük azokat az orvosi paramétereket, amelyek segítségével értékelni tudjuk a transzplantáció sikerességét. A kutatást a Regionális Humán Or- 
vosbiológiai Kutatásetikai Bizottság engedélyezte. Tanulmányunkban 50, cadaver vese-transzplantáción átesett páciens (27 férfi, átlag életkoruk 44,55 év, SD: 12,32 év, illetve 23 nő, átlagos életkoruk 52,82 év, SD: 11,61 év) adatait elemeztük.

\section{Pszichológiai méröeszközök}

A pszichológiai teszteket és kérdőíveket a transzplantációt követő 5. és 10. nap között vettük fel. A szorongásszint és a hangulati állapot mérésére a Spielbergerféle Állapot- és Vonásszorongás Kérdőívet (PERCZEL, Kiss és AJTAY, 2005; SPIELBERgER, GORSuch és Lushene, 1970) és a Beck Depresszió Skálát (BECK, WARD, Mendelson, Mock és ERBAUGH, 1961) alkalmaztuk. A betegség- és testreprezentációkat, illetve a gyógyulással, az idegen eredetű szerv testi és pszichés integrációjával kapcsolatos nézeteket pedig egy általunk kidolgozott rajzteszttel vizsgáltuk. A szakirodalom alapján feltételeztük, hogy ezen projektív technika alkalmas arra, hogy előhívjuk a betegekből a beültetett veséjükkel és a transzplantációval kapcsolatos kevésbé tudatosult érzéseket és fantáziákat, amelyek szimbolikusan tükröződnek a rajzon. A páciensek egy A4-es fehér lapot és 12 színes ceruzát kaptak, és megkértük őket, hogy rajzolják le saját magukat. Amikor elkészültek, a transzplantált veséjük lerajzolása volt a következő instrukció. További utasítást (például a vese helyére vagy méretére vonatkozóan) nem kaptak. Az elemzés során rögzítettük a felhasznált színek számát és a lerajzolt szerv méretét (hosszúság). A testkép integrációs nívójának és komplexitásának értékelésére WITKIN (1962) ötfokú testséma-differenciáltsági skáláját alkalmaztuk. Witkin a testkép különböző szintjeire fókuszált, hogy miképpen érzékeli a személy a saját testét, mint egyértelmü határokkal rendelkező entitást, vagy éppen az ellenkezőjét éli át, a testhatárai széthullását. Értékelte a rajz tagoltságát, formai színvonalát; a részletek mennyiségét; a nemi differenciációt és az egyediszerep-ábrázolást. A magas pontszámot elért személy testsémája tagolt, világos testhatárokkal rendelkezik, a testi tudatosság mértéke kifejezettebb. Az alacsonyabb szinten rajzoló személy nehezen választja külön az érzelmeket a gondolkodástól, tipikus elhárító mechanizmusként a repressziót, a primitív tagadást és a szomatizációt alkalmazza.

\section{Orvosi adatok}

A klinikai vérvizsgálat során meghatározott orvosi paraméterek közül a szérum kreatinin értékét rögzítettük a hazabocsátás előtt, általában a 14. posztoperatív napon, majd három éven keresztül a háromhavonta esedékes kontrollvizsgálatok alkalmával. Továbbá a klinikai és a szövettani kritériumok alapján az akut és/vagy krónikus graft kilökődést (rejekció) is nyomon követtük a mütétet követő három évben. A donor és a recipiens közötti HLA eltéréseket is elemeztük. A humán leukocita antigének (HLA) a sejtek felületén elhelyezkedve segítik az immunrendszert a testazonos és testidegen sejtek azonosításában. Ezenkívül a hideg ischémiás időt és a donor életkorát is rögzítettük a kutatás során. 
A vizsgálati személyeknél a transzplantált szerv működését a rejekciós epizódok és a szérum kreatinin szint alapján értékeltük az eltelt idő alatt. A rejekciós csoport tagjainál egy vagy több rejekciós epizódot észleltünk a műtétet követően, és a veseműködést jelző szérum kreatinin szint nagyobb, mint 180 mol/l. A rejekciómentes csoportnál a műtétet követően nem fordult elő kilökődési reakció, továbbá a szérum kreatinin érték 180 mol/l alatti értéket mutatott.

\section{Statisztikai elemzés}

Az adatokat IBM SPSS 20.0 statisztikai programmal elemeztük. A változók normalitását Shapiro-Wilk-teszttel vizsgáltuk. A szóráshomogenitást Levenepróbával teszteltük. A változók közötti kapcsolatok feltárására Pearson-Spearmanféle korrelációt használtuk. A csoportok összehasonlításánál független mintás t-próbát és Mann-Whitney-próbát alkalmaztunk. A többváltozós logisztikus regresszió segítségével a szervkilökődés prediktorait határozhattuk meg. Statisztikailag szignifikánsnak tekintettük, ahol a $p$ érték kisebb volt, mint 0,05 .

\section{EREDMÉNYEK}

\section{Depresszió és szorongás szervátültetés után}

A transzplantáció után mért állapotszorongás (STAI-S átlag $=37,22, \mathrm{SD}=8,33$ ) átlagértéke a normál tartományba esett. Klinikailag jelentős vonásszorongást (STAI-T > 52 pont) a minta 12\%-a mutatott. Depresszió nem volt kimutatható a mintában (BDI átlag $=3,64, \mathrm{SD}=2,68$ ). A nemek között egyik változó tekintetében sem találtunk szignifikáns különbséget. A depresszió szintje pozitívan korrelál a vonás- és állapotszorongás értékével (STAI-T $r=0,469, p=0,001$, STAI-S $r=0,381, p=0,006, \mathrm{n}=50)$.

\section{Az érzelmi és hangulati állapot és a projektív rajzteszt}

Szignifikáns összefüggést találtunk a depresszió kérdőív és a projektív rajzteszt között. Minél magasabb pontszámot ért el a páciens a depresszió skálán, annál nagyobbra rajzolta a vesét a projektív rajztesztben $(p=0,045, r=0,285, \mathrm{n}=50)$. A magasabb állapot- és vonásszorongást mutató pácienseknél (median alapján STAI-S > 38, STAI-T > 39) szintén nagyobb méretben jelent meg a transzplantált szerv a projektív tesztben (STAI-S $p=0,02, t=2,32, \mathrm{df}=48$; STAI-T $p=0,04$, $t=2,03, \mathrm{df}=48$ ). 
Testképábrázolás és a vese rajza mint a transzplantáció sikerének elörejelzői

3 éves nyomon követéses vizsgálatunkban a beültetett szerv megfelelő működéséről egyrészt a rejekciós epizódok (kilökődés) nyomon követésével, másrészt a laborvizsgálatok értékei (kreatinin szint) alapján nyertünk adatokat. Sajnos a vizsgálati időszak alatt három transzplantált páciensünk meghalt, így a harmadik év végére 47 páciens adatait tudtuk elemezni. Ez időszak alatt 27 főnél nem jelentkezett kilökődési reakció a transzplantációt követő három évben, illetve a szérum kreatinin érték $180 \mu \mathrm{mol} / \mathrm{l}$ alatti értéket mutatott. Rejekciós epizód 20 főnél fordult elő, náluk a szérum kreatinin szint átlagosan 180 mol/l-nél magasabb értéket mutatott. Minden változó tekintetében összehasonlítottuk a két csoportot: szignifikáns különbségeket találtunk a hazabocsátás előtti $(p=0,01)$, az 1 éves $(p<0,001)$, a 2 éves $(p=0,01)$ és a 3 éves $(p<0,001)$ kontrollvizsgálat alkalmával mért szérum kreatinin értékében. Mann-Whitney-próbával szignifikáns különbség mutatkozott a két csoport között a testkép-differenciáltság mértékében $(p=0,01)$ és a rajztesztben felhasznált színek számát $(p=0,01)$ illetően (1. táblázat). Vagyis eredményeink szerint sötétebb, monokróm rajzot készítettek azon személyek, akik a transzplantációt követő három év alatt magasabb kreatinin szintet mutattak, illetve egyszer vagy többször is előfordult, hogy a vese kilökődési reakciót mutatott.

A testkép komplexitásának és integrációs nívójának értékelésére a Witkin-féle ötfokú testséma-differenciáltsági skálát alkalmaztuk. Három független kódoló konszenzusa alapján 1-től 5-ig pontoztuk a rajzokat (2. táblázat). A magas pontszámmal rendelkező rajzokat jó formai színvonal, részletgazdagság és egyedi

1. táblázat. A pszichológiai és az orvosi adatok összehasonlítása a rejekciós epizódok függvényében $(\mathrm{N}=47)$

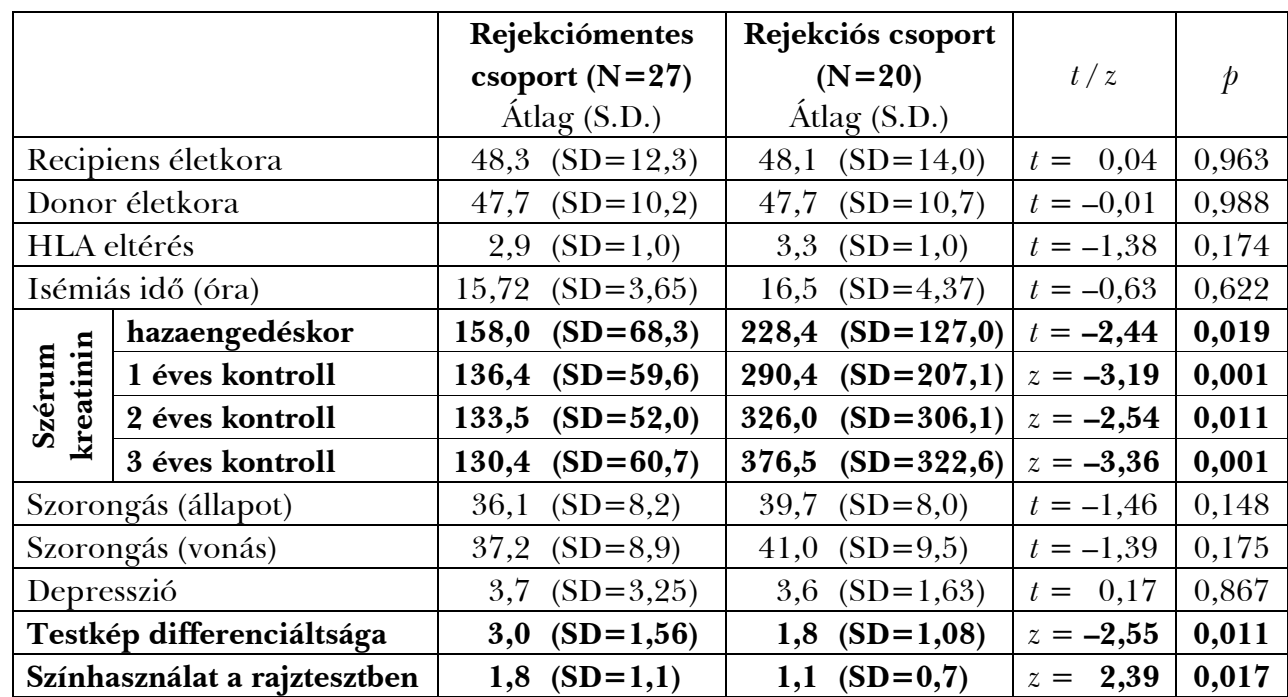


szerep-ábrázolás jellemzi, amely tagolt testképet és világos testhatárokat feltételez. Az alacsonyabb szintű, tagolatlan, részletekben szegényes, differenciálatlan rajzokból pedig a testhatárok széthullására következtethetünk.

2. táblázat. A Witkin-féle testképkomplexitás leíró statisztikája $(\mathrm{N}=47)$

\begin{tabular}{|c|l|c|c|}
\hline \multicolumn{2}{|c|}{ Witkin-féle testképkomplexitás } & Gyakoriság & $\%$ \\
\hline \multirow{4}{*}{ É r t é k } & 1 & 15 & 31,9 \\
\cline { 2 - 4 } & 2 & 14 & 29,8 \\
\cline { 2 - 4 } & 3 & 6 & 12,8 \\
\cline { 2 - 4 } & 4 & 3 & 6,4 \\
\cline { 2 - 4 } & 5 & 9 & 19,1 \\
\hline & Összesen & 47 & 100 \\
\hline
\end{tabular}

Az 1. ábrán a rejekciómentes és a rejekciós csoport rajzaiból láthatunk példákat. A bal oldalon látható rajzok tagoltabb testsémával rendelkeznek, és a kontrollvizsgálatok alkalmával mért szérum kreatinin értékek szignifikánsan alacsonyabbak, mint a rejekciós csoportnál, ahol differenciálatlanabb rajzok készültek.

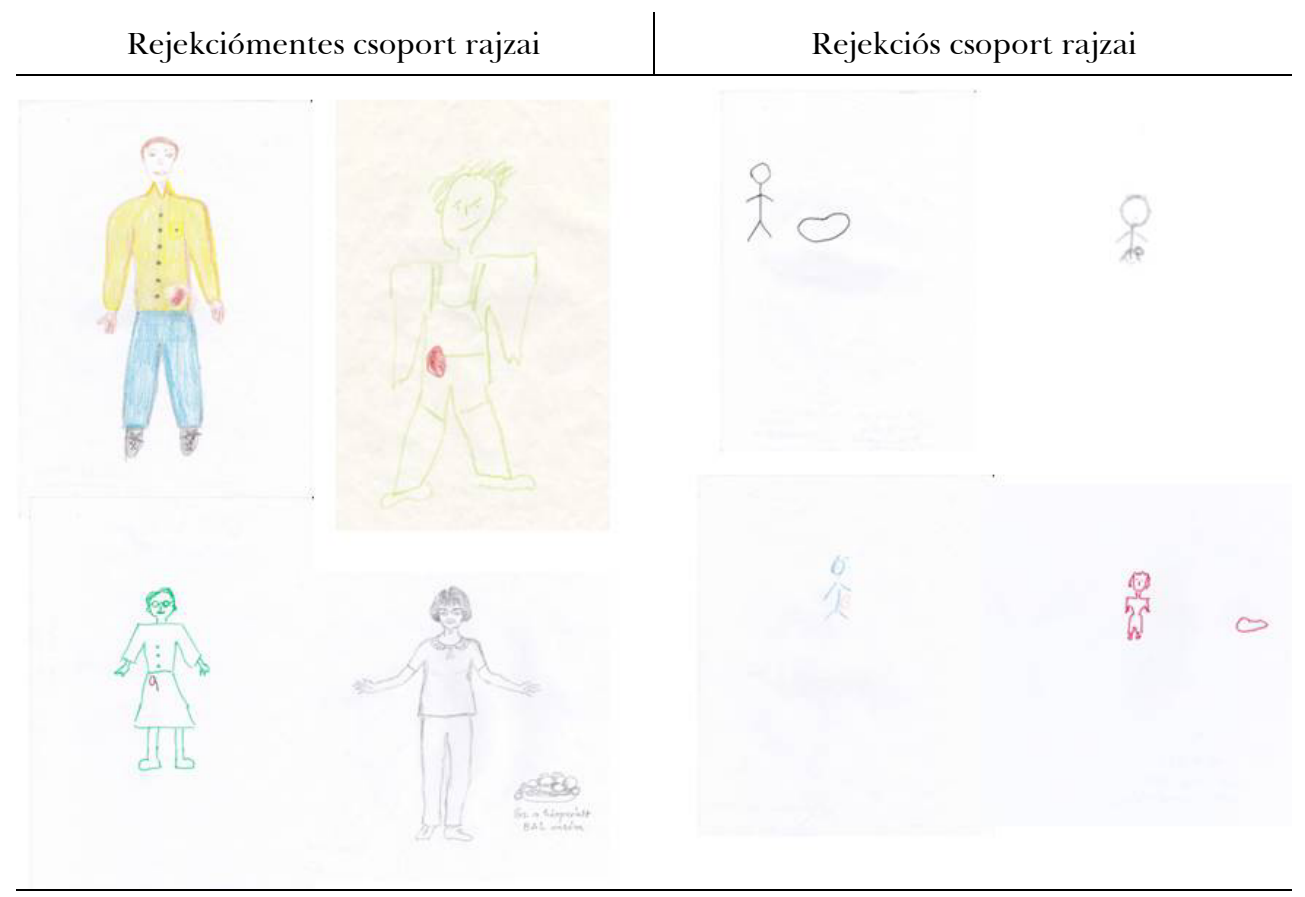

1. ábra. Példák a rejekciómentes és a rejekciós csoport rajzaiból 
Kiemelt kutatási eredményünk, hogy a szerv optimális, hosszú távú működésében a szubjektív testkép reprezentációjának komplexitása meghatározó szerepet játszik. Logisztikus regresszió segítségével - amely a pszichológiai és az orvosi adatokat egyaránt figyelembe veszi - végül két fó változót határoztunk meg a mintánkban, amelyeket a rejekciós epizódok prediktoraiként értékeltünk (3. táblázat). Az omnibus teszt segítségével megállapítottuk, hogy a modellben szereplő független változók a véletlennél nagyobb valószínűséggel állnak kapcsolatban a függő változóval $(p<0,001)$. Sikerült igazolnunk, hogy a testkép differenciáltsága $(\mathrm{OR}=0,28$; $95 \% \mathrm{CI}=0,1-0,82, p<0,02)$ és a hazabocsátás előtt mért szérum kreatinin $(\mathrm{OR}=$ 1,$01 ; 95 \%$ CI $=1,00-1,02, p<0,01$ ) prediktív a 3 éves rejekciós epizódok szempontjából. Az eredményül kapott modell statisztikailag szignifikáns $\left(\chi^{2}=14,91, \mathrm{df}=2\right.$, $p<0,001)$.

3. táblázat. A logisztikus regresszió eredménye.

A rejekciós és a rejekciómentes csoport összehasonlítása

\begin{tabular}{|l|c|c|c|}
\hline \multicolumn{1}{|c|}{ V á l t o z ó k } & $p$ & OR & $95 \%$ CI \\
\hline Szérum kreatinin hazaengedéskor & 0,01 & 1,01 & $1,00-1,02$ \\
\hline Testkép differenciáltsága & 0,02 & 0,28 & $0,1-0,82$ \\
\hline
\end{tabular}

CI - konfidencia intervallum, OR - esethányados

Példaként bemutatjuk két páciensünk rajzát az orvosi és pszichológiai adatokkal együtt (4. táblázat). Megfigyelhetjük, hogy az $A$ jelzésű rajzot készítő páciensnél

4. táblázat. Két transzplantált páciensünk ember- és szervrajza a posztoperatív időszakból, a hozzájuk tartozó pszichológiai és orvosi adatokkal

\begin{tabular}{|c|c|c|c|c|}
\hline A rajz & 34 & Kor & 53 & B rajz \\
\hline & férfi & Nem & férfi & \\
\hline & $26 / 28$ & Szorongás(állapot/vonás) & $27 / 29$ & \\
\hline & 1 & Depresszió & 2 & \\
\hline & 3 & Testkép differenciáltsága & 1 & \\
\hline & 2 & $\begin{array}{l}\text { Színhasználat az alakrajz- } \\
\text { tesztben }\end{array}$ & 1 & \\
\hline & 154 & $\begin{array}{c}\text { Szérum kreatinin } \\
\text { hazabocsátáskor }\end{array}$ & 189 & 0 \\
\hline & 122 & $\begin{array}{l}\text { Szérum kreatinin } \\
1 \text { év múlva }\end{array}$ & 398 & \\
\hline & 112 & $\begin{array}{c}\text { Szérum kreatinin } \\
2 \text { év múlva }\end{array}$ & 796 & \\
\hline & 114 & $\begin{array}{l}\text { Szérum kreatinin } \\
3 \text { év múlva }\end{array}$ & 714 & \\
\hline
\end{tabular}

A rajz: A műtétet követő 3 évben nem fordult elő kilökődési reakció, továbbá a szérum kreatinin érték $180 \mu \mathrm{mol} / \mathrm{l}$ alatti értéket mutat. $B$ rajz: Több rejekciós epizódot észleltünk a mủtétet követő 3 évben, és a veseműködést jelző szérum kreatinin szint átlagosan nagyobb, mint $180 \mu \mathrm{mol} / \mathrm{l}$. 
nem volt kilökődési reakció a transzplantációt követő három évben és a rajz színvonala is magasabb, mint a $B$ jelzésű páciensnél, akinél a vese allograft múködésképtelensége miatt dialízis vált szükségszerűvé.

\section{DISZKUSSZIÓ}

A szervátültetés intrapszichés konfliktusokat eredményezhet, megbonthatja a testkép integritását, mely a gyógyulási folyamatot is befolyásolja. Kutatásunkban feltérképeztük a transzplantáció utáni testkép-jellegzetességeket és azok potenciális hatását a szerv hosszú távú működésére. Eredményeink szerint a testkép komplexitása és a beültetett szerv mentális reprezentációinak sajátosságai összefüggésben állnak a gyógyulási folyamat minőségét tükröző élettani mutatókkal és az affektív jellemzőkkel.

Vizsgálatunk során a pácienseknél mért állapotszorongás átlagértéke a normál tartományba esett, melynek oka lehet, hogy a tesztfelvétel megfelelő pszichológiai előkészítés után történt, ami önmagában is szorongáscsökkentő hatású. Szervátültetés után azonban a páciensek számára fizikailag és pszichológiai értelemben is nagyon nehéz időszak következik. Az átültetett szerv pszichológiai szinten még nem saját, az úgynevezett „pszichés transzplantáciō” még várat magára (PASQUALE és mtsai, 2010). Vizsgálatunkban a szorongóbb és depresszívebb páciensek nagyobb méretben jelenítették meg a transzplantált szervet a projektív rajzteszten. Feltételezésünk szerint a negatívabb érzelmi és hangulati állapot a szerv mentális reprezentációjának „felnagyítódásával” járhat együtt. Ha az „idegen test” által kiváltott szorongás nem oldódik meg, és a személy képtelen az új szervet testképébe integrálni, az komoly problémákhoz, súlyos esetben a beültetett vese elvesztéséhez is vezethet (CASTELNUOVO-TEDESCO, 1983; JORALEMON, 1995).

Lineáris regressziós modellel sikerült igazolnunk a testkép komplexitásának és a transzplantáció után, a hazaengedés előtt mért szérum kreatinin szintnek a bejósló erejét is. Ezen eredményünk összhangban van DiCKENMANN és munkatársai (2002) vizsgálatával, melyben szintén sikerült igazolni a plazma kreatinin prediktív értékét a graft kilökődésében. Értelmezésünk szerint a kevésbé komplex, differenciálatlanabb rajz a testkép integritásának sérülésére utal. Ez összefüggésben állhat az elszigeteltség és az alacsonyabb önbecsülés érzésével is, mely a terápiás együttműködésre (kontrollra járás, gyógyszerek pontos szedése) és az általános megküzdési képességekre is negatív hatást gyakorol (Nesci, Favale, Foco, CASTAGNETo és NANNI, 2001). Továbbá a kevésbé részletes rajz a szorongás egyik indikátorának is tekinthető, ami a lassabb fizikai és lelki felépüléssel is összefüggésben áll (HANDler, 1967; HJorth és Harway, 1981; Horwitz, Kowalski, THEOREll és ANDERBERG, 2006; MACHOVER, 1949). Eredményeink szerint a sötétebb, monokróm rajzok gyakrabban fordultak elő a graft rejekciót mutató csoportban. A sötét színek a rajztesztekben a harag, a fájdalom és a félelem érzéséhez kapcsolódnak (VASS, 2011).

Kutatásunk célja a transzplantáció utáni testkép-jellegzetességek vizsgálata. Azonban a műtét utáni rövid időszakban ennek a komplex pszichológiai élmény- 
nek a rendeződése, a testkép újbóli integrálódása nem feltétlen következhet be. Továbbá a páciens által észlelt fizikális tünetek mennyisége, súlyossága és egyéni jelentése is meghatározó lehet abban, hogy a személy mennyire képes integrálni az új szervet a testképébe. A kutatás további korlátjának tekinthető a viszonylag kevés elemszám. A vizsgálati mintát és kutatási adatainkat ezért folyamatosan bővítjük, a kérdőíveket és a rajzteszteket a transzplantáció utáni második és harmadik év között ismételten felvesszük a pácienseinkkel. Hosszú távon egyéb változókat is kontrollálunk, melyek a kilökődésnek és a vizsgált kapcsolatoknak módosító tényezői lehetnek.

Kutatási eredményeink szerint az általunk alkalmazott tesztbattéria alkalmas a transzplantáció komplex, világviszonylatban is kevésbé kutatott pszichoszomatikus mechanizmusainak a mélyebb megértésére. Eredményeink a pszichológiai intervenció fontosságára is felhívják a figyelmet, amellyel a transzplantáción átesett páciensek minél teljesebb gyógyulását segíthetjük elő. A szakirodalom és a klinikai tapasztalat szerint az „idegen test” problémájának megoldását az internalizáció folyamata segíti elő, mely során a személy az objektív, valós tapasztalatokat és a benne lejátszódott, fantáziált interakciókat belsővé teszi (MENTzos, é.n.; MusLinM, 1971). Azáltal, hogy a pszichológus megérti és elfogadja mindazokat az érzéseket, élményeket, tapasztalatokat és félelmeket, amelyek a páciensben megjelennek, egyúttal könnyebben integrálhatóvá is teszi azokat. Klinikai tapasztalataink szerint a szupportív, kliensközpontú terápia a gyógyító személyzettel való együttműködésre is pozitív hatást gyakorol, ugyanis a páciensek jobban követik az orvosi utasításokat, pontosan szedik a gyógyszereket és nem halasztják el a kontrollvizsgálatokon való megjelenést sem. Kutatásunk további, hosszú távú célja, hogy a transzplantációs várólistán lévő betegek pszichológiai szűrésével előre jelezzük, hogy a páciens mennyire lesz képes tolerálni a transzplantációt kísérő komplex tapasztalatot. Ezen megküzdési folyamat segítéséhez célzott pszichológiai tanácsadási eljárást dolgozunk ki.

\section{IRODALOM}

BAGDY E. (1998). Az alak-rajz teszt, mint projektív vizsgálati módszer. In MÉREI F. és SZAKÁCS F. (szerk.), Pszichodiagnosztikai vademecum II. Személyiségtesztek 2. rész (148-182). Budapest: Tankönyvkiadó.

BASCH, S. H. (1973). The intrapsychic integration of a new organ - A clinical study of kidney transplantation. The Psychoanalytic Quarterly, 42, 364-384.

Beck, A. T., Ward, C. H., Mendelson, M., Mock, J., \& Erbaugh, J. (1961). An inventory for measuring depression. Archives of General Psychiatry, 4, 561-571.

Broadbent, E., Ellis, C. J., Gamble, G., \& Petrie, K. (2006). Changes in patient drawings of the heart identify slow recovery after myocardial infarction. Psychosomatic Medicine, 68, 910-913.

Calia, R., lai, C., Aceto, P., luciani, M., Saraceni, C., Avolio, A. W., \& Agnes, S. (2011). Psychological risk factors for graft rejection among liver transplant recipients. Transplantation Proceedings, 43, 1123-1127. 
Calia, R., Lai, C., Aceto, P., Luciani, M., Saraceni, C., Lai, S., Gargiulo, A., \& CitTERIO, F. (2011). Preoperative psychological factors predicting graft rejection in patients undergoing kidney transplant: A pilot study. Transplantation Proceedings, 43, 1006-1009.

Castelnuovo-Tedesco, P. (1983). Organ transplant, body image, psychosis. The Psychoanalytic Quarterly, 42, 349-363.

Consoli, E. (2012). Person-centered approach in the medicine of organ transplants. Letöltve: 2013. november 4-én: http://www.psicoanalisi.it/psicoanalisi/osservatorio/articoli/osservaing 1 132.htm

Csabai M. és ERŐS F. (2000). Testhatárok és énhatárok. Budapest: Jószöveg Műhely.

De Pasquale, C., Pistorio, M. L., Sorbello, M., Parrinello, L., Corona, D., Gagliano, M., Giuffrida, G., Giaquinta, A., Sinagra, N., Zerbo, D., Veroux, P., \& Veroux, M. (2010). Body image in kidney transplantation. Transplantation Proceedings, 42, 11231126.

Dickenmann, M. J., Nickeleit, V., Tsinalis, D., Gurke, L., Mihatsch, M. J., \& Thiel, G. (2002). Why do kidney grafts fail? A long-term single-center experience. Transplant International, 15, 508-514.

Fordham, M. (1971). Primary self, primary narcissism and related concepts. Journal of Analytical Psychology, 16, 168-187.

HANDler, L. (1967). Anxiety indexes in the Draw-A-Person test: A scoring manual. Journal of Projective Techniques and Personality Assessment, 31, 46-57.

HJORTh, C. W., \& HARWAY, M. (1981). The body-image of physically abused and normal adolescents. Journal of Clinical Psychology, 37, 863-866.

Horwitz, E. B., Kowalski, J., Theorell, T., \& AnderberG, U. M. (2006). Dance/movement therapy in fibromyalgia patients: Changes in self-figure drawings and their relation to verbal self-rating scales. The Arts in Psychotherapy, 33, 11-25.

Ilić, S., \& Avramović, M. (2002). Psychological aspects of living donor kidney transplantation. Medicine and Biology, 9, 195-200.

Joralemon, D. (1995). Organ wars: The battle for body parts. Medical Anthropology Quarterly, 9, 335-356.

LÁtos, M., LázÁr, Gy., Marofka, F., Szederkényi, E., Szenohradszky, P., Barabás, K., \& CSABAI, M. (2012). Mental representation of the new organ and posttransplant patient's anxiety as related to kidney function. Transplantation Proceedings, 44, 2143-2145.

Machover, K. (1949). Personality Projection in the Drawing of the Human Figure. Springfield: Charles C. Thomas.

Machover, K. (1951). Drawing of the human figure: A method of personality investigation. In H. H. Anderson, \& G. L. Anderson (Eds.), An Introduction to Projective Techniques (341-369). New York: Prentice Hall.

Mentzos, S. (é. n.). A konfliktus-feldolgozás neurotikus módjai. Budapest: Lélekben Otthon.

Muslinm, H. L. (1971). On acquiring a kidney. Americal Journal of Psychiatry, 127, 11851188.

Nesci, D. A., Favale, C., Foco, M., Castagneto, M., \& Nanni, G. (2001). Psychodynamic evaluation of kidney transplant patients enrolled in a new immunosuppressive drug trial. Transplantation Proceedings, 33, 1907-1908. 
Perczel F. D., Kiss Zs. és AJTAy Gy. (2005). Kérdőívek, becslőskálák a klinikai pszichológiában. Budapest: Országos Pszichiátriai és Neurológiai Intézet.

Pérez-San-Gregorio, M. A., Martín-Rodríguez, A., Galán-Rodríguez, A., \& BordaMÁs, M. (2009). Living and deceased transplanted patients one year later: Psychosocial differences just after surgery. International Journal of Clinical and Health Psychology, 9, $429-438$.

Shimazono, Y. (2013). Accommodating a "foreign" organ inside the body: Post-transplant bodily experiences of Filipino kidney recipients. Ars Vivendi Journal, 3, 24-50.

Spielberger, C. D., Gorsuch, R. L., \& Lushene, R. E. (1970). Manual for the State-trait Anxiety Inventory. Palo Alto: Consulting Psychologists Press.

Urban, E. (é. n.). Post-Jungian developmental theory: Michael Fordham's model of development. Letöltve: 2014. június 1-jén:

http://www.thesap.org.uk/post-jungian-developmental-theory

VASS Z. (2006). A rajzvizsgálat pszichodiagnosztikai alapjai. Budapest: Flaccus.

VASs Z. (2011). A képi kifejezéspszichológia alapkérdései. Szemlélet és módszer. Budapest: L'Harmattan.

Witkin, H. A. (1962). Articulation of the body concept. In H. A. Witkin, R. B. Dyk, H. F. Faterson, D. R. Goodenough, \& S. A. Karp (Eds.), Psychological Differentiation (115133). New York: Wiley.

\title{
BODY BOUNDARIES AND THE SUCCESSFUL ORGAN TRANSPLANTATION. LONGITUDINAL STUDY OF RENAL TRANSPLANT PATIENTS
}

\author{
LÁTOS, MELINDA - DEVECSERY, ÁGNES - LÁZÁR, GYÖRGY - HORVÁTH, ZOLTÁN - \\ SZENOHRADSZKY, PÁL - SZEDERKÉNYI, EDIT - CSABAI, MÁRTA
}

Objective: A wide range of interdisciplinary investigations suggest that transplantation may also create self-representation problems and vulnerability of the body image (CALIA et al, 2011; PASQUALE et al, 2010). Our study's aim was exploring body image characteristics after kidney transplantation, and their relationships with long-term renal outcomes.

Methods: 50 cadaver kidney transplant patients were assessed using a combined self-and organ drawing test; with the Spielberger State-Trait Anxiety Inventory, and the Beck Depression Inventory. Medical parameters from routine clinical blood tests were collected quarterly for three years after transplantation.

Results and conclusions: The patients with higher anxiety and depression drew their implanted kidney larger, which might refer to complications in the normal intrapsychic integration of the organ. Logistic regression analysis showed that the integrity of the body image together with pre-discharge serum creatinine levels were significant predictors of graft rejection episodes. Our results suggest that the patients' post-transplant body- and self-image problems might contribute to graft-rejection, and decreased health outcomes.

Key words: $\quad$ body image, transplantation, drawing-test, anxiety 